\title{
Does Nitrous Oxide Affect the Corneal Endothelium? A Prospective Randomized Study in Pediatric Patients*
}

\author{
Nitröz Oksit Korneal Endoteli Etkiler mi? Pediyatrik Hastalarda \\ Prospektif Randomize Bir Çalışma
}

\begin{abstract}
Aim: In this study, we aimed to evaluate the mean changes in the corneal endothelial cells and pachymetry values of patients who underwent general anesthesia with sevoflurane with N2O or 02 .

Materials and Methods: Forty eyes of 40 patients who had extraocular surgery under general anesthesia were included in this prospective study. The patients were divided into two groups as the 02 and $\mathrm{N} 2 \mathrm{O}$ groups, for which \%50 02 (total flow rate; $2 \mathrm{~L} / \mathrm{min}$ in 02 -air mixture) and \%50 02 (total flow rate; $2 \mathrm{~L} / \mathrm{min}$ in $\mathrm{O} 2-\mathrm{N} 2 \mathrm{O}$ mixture) were used, respectively. The duration of the surgery was recorded. The CD (cell density), CV (cell variation), Hex (hexagonality rate) and pachymetric specular microscopy results were evaluated before surgery, and at the first and fourth weeks after surgery.

Results: The surgical duration and demographic data of the groups were similar, and there was no statistically significant difference between the two groups. The value of CV was $26 \pm 2 \mathrm{cell} / \mathrm{mm} 2$ for the 02 group and 30 cell/mm2 for the N2O group at the first week. There was a statistically significant increase in the $\mathrm{N} 2 \mathrm{O}$ group values, compared to the preoperative values $(p=0.008)$. The Hex value was $52 \pm 10 \%$ for the $\mathrm{O} 2$ group and $62 \pm 11 \%$ for the N2O group at the first postoperative week, and there was a statistically significant increase in the $\mathrm{N} 2 \mathrm{O}$ group values in comparison to the preoperative values $(p=0.007)$. There was no significant difference between the two groups in terms of $\mathrm{CD}, \mathrm{CV}, \mathrm{Hex}$, and pachymetry at other times.

Discussion and Conclusion: Statistically significant change was observed the first postoperative week in the corneal variation and hexagonality rate values of the pediatric patients who underwent general anesthesia with nitrous oxide. More studies need to be done for further assessments.

Keywords: nitrous oxide; corneal endothelium; child; general anesthesia
\end{abstract}

\section{Öz}

Amaç: Bu çalışmada sevofluran ve $\mathrm{N} 2 \mathrm{O}$ veya $\mathrm{O} 2$ karışımıyla genel anestezi uygulanan hastaların korneal endotel hücre ve pakimetri değerlerindeki ortalama değişiklikleri değerlendirmek amaçlanmıştır. Gereç ve Yöntemler. Bu prospektif çalışmaya genel anestezi altında ekstraoküler cerrahi uygulanan 40 hastanın 40 gözü dahil edildi. Hastalar N2O ve 02 grubu olarak iki gruba ayrıldı. Her bir grupta \%50 $\mathrm{O} 2$ (toplam debi; O2 -hava karışımı içinde $2 \mathrm{~L} / \mathrm{dk}$ ) ve \%50 O2 (toplam debi; O2-N2O karışımı içinde $2 \mathrm{~L} / \mathrm{dk}$ ) kullanıldı. Ameliyat süresi kaydedildi. Cerrahi öncesinde ve de ameliyattan 1 hafta ve 4 hafta sonra hücre yoğunluğu (CD-cell density), hücre değişimi (CV-cell variation), heksagonalite oranı (Hex) ve pakimetrik speküler mikroskopi sonuçları değerlendirildi.

Bulgular. Grupların ameliyat süre ve demografik verileri benzerdi ve gruplar arasında istatistiksel olarak anlamlı fark yoktu. CV değeri birinci haftada $\mathrm{O} 2$ grubunda $26 \pm 2$ hücre/mm2, N2O grubunda ise 30 hücre/mm2 olarak saptandı. N2O grubu verilerinde preoperatif değerlere kıyasla istatistiksel olarak anlamlı bir artış vardı ( $p=0,008)$. Hex değeri birinci haftada 02 grubunda \%52 \pm 10 , N2O grubunda ise $\% 62 \pm 11$ olarak saptandı. Yine N2O grubu verilerinde preoperatif değerlere kıyasla anlamlı artış vardı $(p=0,007)$. Diğer zamanlarda CD, CV, Hex, pakimetri verileri açısından gruplar arasında anlamlı bir fark yoktu.

Tartışma ve Sonuç: Nitröz oksit karışımı ile genel anestezi uygulanan pediyatrik hastaların korneal varyasyon ve heksagonalite oranı değerlerinde postoperatif birinci haftada anlamlı değişiklik saptanmıştır. Daha ileri değerlendirmeler için daha fazla çalışmaya intiyaç vardır.

Anahtar Sözcükler. nitröz oksit; kornea endoteli; çocuk; genel anestezi
Ahmet Selim Özkan', Sedat Akbaş', Nihat Polat², Mehmet Rıdvan Yalın'

İnönü Üniversitesi Tıp Fakültesi,

Anesteziyoloji ve Reanimasyon Anabilim Dalı, Malatya, Türkiye

2 İnönü Üniversitesi Tıp Fakültesi, Göz Hastalıkları, Malatya, Türkiye

Geliş Tarihi /Received : 28.11.2017 Kabul Tarihi /Accepted: 16.12.2017

DOI: 10.21673/anadoluklin.358521

Sorumlu Yazar/Corresponding Author Ahmet Selim Özkan

Turgut Özal Tıp Merkezi, Malatya, Türkiye E-mail: asozkan61@yahoo.com

Bu çalışma, 25-28 Mayıs 2017'de İstanbul'da gerçekleştirilen Göğüs Kalp Damar Anestezi ve Yoğun Bakım Derneği 23. Ulusal Kongresi'nde e-poster olarak sunulmuştur. 


\section{INTRODUCTION}

General anesthesia is commonly used in millions of patients worldwide every year, and volatile anesthetic agents are frequently used during general anesthesia. There are many studies on the effects of volatile anesthetics. For example, it was shown that volatile anesthetics could cause endothelial damage by polymorphonuclear neutrophil adhesion (1). Although nitrous oxide $\left(\mathrm{N}_{2} \mathrm{O}\right)$ has been used securely and commonly as an analgesic and sedative or volatile anesthetic, it has also been propounded that $\mathrm{N}_{2} \mathrm{O}$ use during general anesthesia can lead to complications, such as perioperative cardiac arrest and death (2).

Nitrous oxide irreversibly reduces methionine synthase enzyme activity and increases the plasma concentration of homocysteine as a result, and continues to affect for at least one week after surgery (3). Two hours of exposure to $\mathrm{N}_{2} \mathrm{O}$ is associated with a $50 \%$ decline in methionine synthase enzyme activity (4). An acute increase in the plasma concentration of homocysteine can cause endothelial dysfunction (5).

The corneal endothelium is composed of singlelayer hexagonal cells. The number and formation (density, hexagonality, etc.) of the corneal cells can be reduced by several factors such as aging, trauma, and surgery (6). This causes different cell sizes and appearances (polymegathism), a decrease in the ratio of hexagonal cells (pleomorphism), and an increase in cells with different geometric shapes (7). In this study, corneal cell density $(\mathrm{CD})$, coefficient of variation (CV), hexagonality rate (Hex), and pachymetric specular microscopy results were evaluated before surgery, and at the first and fourth weeks after surgery. CD was used to describe the biological and histological characteristics of the cornea. CD could be high in inflammation areas in the cornea. Hexagonal cell percentage gradually decreases from $75 \%$ every year (8).

Nitrous oxide is frequently used with sevoflurane during general anesthesia. Several adverse effects of $\mathrm{N}_{2} \mathrm{O}$ are known, such as megaloblastic anemia, homocyteinemia, thrombosis, neurotoxicity, increased intracranial pressure, cerebral blood flow, expansion of air space and hypoxia, postoperative vomiting, and possible immune suppression (9). However, endothelial effects of $\mathrm{N}_{2} \mathrm{O}$ use on the corneal endothelium have not been investigated thoroughly, and there is insuf- ficient information. $\mathrm{N}_{2} \mathrm{O}$ is also likely to cause toxic effects on the corneal endothelium. The aim of this study was to evaluate the mean changes in the corneal endothelial cells and pachymetry values measured by specular microscopy of pediatric patients who underwent general anesthesia with sevoflurane with $\mathrm{N}_{2} \mathrm{O}$ or $\mathrm{O}_{2}$.

\section{MATERIALS AND METHODS}

This study was planned and conducted between January 2017 and July 2017 in accordance with the Helsinki Declaration and the Clinical Research Ethics Committee (reference number 2017-95) of the Inonu University. The study was registered on ClinicalTrials.gov (NCT03006211). Informed consent of the parent(s) of each pediatric patient was obtained. Forty eyes of 40 pediatric patients whose ASA (American Society of Anesthesiologists) scores were I to II and who underwent extraocular surgery under general anesthesia were included in this prospective study. $\mathrm{Pa}$ tients who had uveitis, glaucoma, retinopathy, corneal dystrophy, history of intraocular surgery, history of globe trauma, any systemic disease, and any complication during or after surgery were excluded.

Children aged between 1 and 14 years who underwent general anesthesia were included in this prospective and randomized study. The $\mathrm{CD}, \mathrm{CV}, \mathrm{Hex}$, and pachymetric specular microscopy results (measured by NSP 9900 noncontact specular microscopy, Konan Medical Inc., Nishinomiya, Japan) before surgery, and at the first and fourth weeks after surgery were analyzed. The patients were divided into two groups as the $\mathrm{O}_{2}(\mathrm{n}=20)$ and $\mathrm{N}_{2} \mathrm{O}(\mathrm{n}=20)$ groups. $\% 50 \mathrm{O}_{2}$ (total flow rate; $2 \mathrm{~L} / \mathrm{min}$ in $\mathrm{O}_{2}$-air mixture) was used in the $\mathrm{O}_{2}$ group and $\% 50 \mathrm{O}_{2}$ (total flow rate; $2 \mathrm{~L} / \mathrm{min}$ in $\mathrm{O}_{2}-\mathrm{N}_{2} \mathrm{O}$ mixture) in the $\mathrm{N}_{2} \mathrm{O}$ group, with sevoflurane use in both groups.

All of the patients were preoperatively evaluated for general anesthesia and stopped consuming solid foods six hours prior to the operation. Midazolam (0.5 $\left.\mathrm{mg} \cdot \mathrm{kg}^{-1}\right)$ administered orally was used for premedication and fifteen minutes later they entered the operating room as part of the routine practice of our clinic. All of the patients were preoxygenated with $100 \% \mathrm{O}_{2}$ $6 \mathrm{~L} / \mathrm{min}$ for three minutes at the beginning of anesthesia. In all of the cases standard anesthesia induc- 
Table 1. Clinical characteristics of the patients

\begin{tabular}{lll}
\hline Characteristics & $\begin{array}{l}\text { Group } \mathrm{O}_{2} \\
(\mathrm{n}=20)\end{array}$ & $\begin{array}{l}\text { Group } \mathrm{N}_{2} \mathrm{O} \\
(\mathrm{n}=20)\end{array}$ \\
\hline Age $(\mathrm{yr})$ & $9 \pm 3.7$ & $10 \pm 2.8$ \\
\hline Male sex & $11(55 \%)$ & $10(50 \%)$ \\
\hline ASA physical status & & \\
\hline I & $17(85 \%)$ & $14(70 \%)$ \\
\hline II & $3(15 \%)$ & $6(30 \%)$ \\
\hline Duration of anesthesia $(\min )$ & $80 \pm 15$ & $90 \pm 10$ \\
\hline
\end{tabular}

Data in $\mathrm{n}(\%)$ or mean $\pm \mathrm{SD}$; min: minute; ASA: The American Society of Anesthesiologists

tion (propofol $2 \mathrm{mg} \cdot \mathrm{kg}^{-1} \mathrm{IV}$, fentanyl $1 \mu \mathrm{g} \cdot \mathrm{kg}^{-1} \mathrm{IV}$ ) was performed and airway control was provided by laryngeal mask airway. Both the $\mathrm{O}_{2}$ group $\left(\% 50 \mathrm{O}_{2}\right.$ total flow rate; $2 \mathrm{~L} / \mathrm{min}$ in $\mathrm{O}_{2}$-air mixture) and the $\mathrm{N}_{2} \mathrm{O}$ group (\%50 $\mathrm{O}_{2}$ total flow rate; $2 \mathrm{~L} / \mathrm{min}$ in $\mathrm{O}_{2}-\mathrm{N}_{2} \mathrm{O}$ mixture) were administered with \%1-2 MAC sevoflurane. Parameters for mechanical ventilation were tidal volume; 6-8 ml.kg-1 , I/E ratio; 1:2. Frequency of respiration was provided with adequate limits to fix $\mathrm{EtCO}_{2}$ at $35-45 \mathrm{mmHg}$. Anesthetic agents was stopped and the patients were ventilated by $100 \% \mathrm{O}_{2}$ and extubated when spontaneous ventilation was sufficient at the end of the surgery. The duration of anesthesia was determined as the interval from the induction of anesthesia to the tracheal extubation. The corneal measurements were performed before the surgery, and at the first and fourth postoperative weeks.

\section{Statistical Analysis}

For statistical analysis, Statistical Package for the Social Sciences (SPSS) version 22.0 (SPSS, Inc., Chicago, IL) software was used. The Mann-Whitney U and Friedman tests were used to compare the preoperative and postoperative values. The data were denoted as mean \pm standard deviation (SD). $p$ values less than 0.05 were accepted as statistically significant.

\section{RESULTS}

The surgical duration and demographic data of the groups were similar and there was no significant difference between the two groups. The clinical characteristics of the groups are shown in Table 1 . The duration of anesthesia for the $\mathrm{O}_{2}$ group was $80 \pm 15 \mathrm{~min}$ and $90 \pm 10 \mathrm{~min}$ for the $\mathrm{N}_{2} \mathrm{O}$ group. The measured changes in the corneal endothelial specular microscopy values are shown in Table 2. The $\mathrm{CV}$ value for the $\mathrm{O}_{2}$ and $\mathrm{N}_{2} \mathrm{O}$ groups at the first week was $26 \pm 2 \mathrm{cell} / \mathrm{mm}^{2}$ and $30 \mathrm{cell} /$ $\mathrm{mm}^{2}$, respectively, and there was a statistically significant increase in the $\mathrm{N}_{2} \mathrm{O}$ group values in comparison to the preoperative values $(\mathrm{p}=0.008)$. The Hex value was $52 \pm 10 \%$ for the $\mathrm{O}_{2}$ group and $62 \pm 11 \%$ for the $\mathrm{N}_{2} \mathrm{O}$ group at the first postoperative week, and there was again a statistically significant increase in the $\mathrm{N}_{2} \mathrm{O}$ group values in comparison to the preoperative values $(\mathrm{p}=0.007)$. There was no significant difference between the two groups in terms of CD, CV, Hex, and pachymetry at other times.

\section{DISCUSSION AND CONCLUSION}

The most commonly used agents in general anesthesia are $\mathrm{N}_{2} \mathrm{O}, \mathrm{O}_{2}$, and sevoflurane. $\mathrm{N}_{2} \mathrm{O}$ is one of the oldest anesthetics and a widely used gas in humans. $\mathrm{N}_{2} \mathrm{O}$ has been used extensively in anesthesia practices for many years, and many studies have been conducted concerning its useful and harmful effects. $\mathrm{N}_{2} \mathrm{O}$ is usually preferred in combination with volatile anesthetic agents for its low potency and taking advantage of seconder gas effect. Our study assessed the effects of $\mathrm{N}_{2} \mathrm{O}$ on the corneal endothelium. The duration of exposure to $\mathrm{N}_{2} \mathrm{O}$ was standardized for each group as approximately 90 minutes. It had been considered that changes in the duration of exposure could affect the results.

It has been shown that some reasons such as trauma, toxicity, surgery, or extra damage affect the corneal endothelium (10). In this study, it was found that $\mathrm{N}_{2} \mathrm{O}$ affected only coefficient of variation and hexagonality rate of the corneal endothelium in the first postoperative week values (Table 2). There was no change in the values at other times because of short-term exposure to $\mathrm{N}_{2} \mathrm{O}$ or the low number of the cases. Pachymetry was used as a marker of acute changes in the corneal endothelium. Besides, the cases were followed up until the fourth postoperative week to investigate the longterm effects of $\mathrm{N}_{2} \mathrm{O}$ on the corneal endothelium.

Several factors such as being female, age, and obesity were defined as factors affecting the toxicity of anesthetic gases for organs (10). The patients in this study were younger and had normal body mass index. 
Table 2. Changes in the corneal endothelial specular microscopy values

\begin{tabular}{|c|c|c|c|c|c|}
\hline Variables & & $\begin{array}{l}\text { values } \\
\text { D) }\end{array}$ & $\begin{array}{c}\text { First postoperative week } \\
\text { values } \\
(\text { mean } \pm \text { SD })\end{array}$ & $\begin{array}{c}\text { First postoperative month } \\
\text { values } \\
(\text { mean } \pm S D)\end{array}$ & $p$ \\
\hline \multirow{2}{*}{$\begin{array}{l}\mathrm{CD} \\
\left(\mathrm{cell} / \mathrm{mm}^{2}\right)\end{array}$} & Group $\mathrm{O}_{2}$ & $3063 \pm 216$ & $3079 \pm 196$ & $3094 \pm 226$ & \multirow{2}{*}{0.835} \\
\hline & Group $\mathrm{N}_{2} \mathrm{O}$ & $3078 \pm 231$ & $3145 \pm 164$ & $3087 \pm 171$ & \\
\hline \multirow{2}{*}{$\mathrm{CV}$} & Group $\mathrm{O}_{2}$ & $26 \pm 0.4$ & $26 \pm 0.3$ & $27 \pm 0.3$ & \multirow{2}{*}{0.008} \\
\hline & Group $\mathrm{N}_{2} \mathrm{O}$ & $25 \pm 0.3$ & $30 \pm 0.2$ & $28 \pm 0.5$ & \\
\hline \multirow{2}{*}{ Hex (\%) } & Group $\mathrm{O}_{2}$ & $51.6 \pm 10$ & $52.5 \pm 10$ & $52.2 \pm 9$ & \multirow{2}{*}{0.007} \\
\hline & Group $\mathrm{N}_{2} \mathrm{O}$ & $51.5 \pm 10$ & $62.5 \pm 11$ & $57.1 \pm 9$ & \\
\hline \multirow{2}{*}{ Pachymetry $(\mu \mathrm{m})$} & Group $\mathrm{O}_{2}$ & $566 \pm 29$ & $569 \pm 31$ & $560 \pm 38$ & \multirow{2}{*}{0.466} \\
\hline & Group $\mathrm{N}_{2} \mathrm{O}$ & $574 \pm 38$ & $574 \pm 36$ & $573 \pm 37$ & \\
\hline
\end{tabular}

CD: cell density; $\mathrm{CV}$ : coefficient of variation; Hex: hexagonality rate; $\mathrm{O}_{2}$ : oxygen; $\mathrm{N}_{2} \mathrm{O}$ : nitrous oxide

Some studies indicated that volatile anesthetics such as isoflurane or xenon induced preconditioning by decreasing protein kinase $\mathrm{C}$ and some protein varieties (11). Polat et al. stated that general anesthesia with sevoflurane did not have a toxic effect on the corneal endothelium and did not change the cell number and cell morphology in the corneal endothelium. $\mathrm{N}_{2} \mathrm{O}$ was not used during general anesthesia (12).

The corneal endothelial cells are not regenerative. The CV and Hex ratios (pleomorphism and polymygatism) in the endothelium are remodeling indicators, and the remodeling of the corneal endothelium after damage can last for up to 3 months $(7,13)$. This may cause a limitation; however, in this study it was considered that $\mathrm{N}_{2} \mathrm{O}$ would not be effective on the corneal endothelium at these doses for up to 3 months. Besides, in a similar study, the duration was limited to 1 month (14). Following studies can be planned with high doses and long-term exposure to $\mathrm{N}_{2} \mathrm{O}$ for up to 3 months, and long-term effects of $\mathrm{N}_{2} \mathrm{O}$ can be investigated.

The effect of $\mathrm{N}_{2} \mathrm{O}$ on vitamin $\mathrm{B}_{12}$ can cause to endothelial dysfunction. Myles et al. suggested a relationship between plasma homocysteine concentration and endothelial dysfunction after using $\mathrm{N}_{2} \mathrm{O}$-based anesthesia, and that endothelial dysfunction due to $\mathrm{N}_{2} \mathrm{O}$ use could be a risk factor for postoperative cardiovascular morbidity (15). In their study, the median duration of exposure to $\mathrm{N}_{2} \mathrm{O}$ was greater than 4 hours. $\mathrm{N}_{2} \mathrm{O}$ exposure effects increased postoperative homocysteine levels significantly. Increased plasma homocysteine levels can go on for 1 week after surgery (3). In addition, exposure to $\mathrm{N}_{2} \mathrm{O}$ for more than 2 hours reduce methionine synthase activity and high plasma homocysteine values at the rate of $50 \%$ (4). It was reported in Myles' study that the duration of $\mathrm{N}_{2} \mathrm{O}$ exposure was significantly associated with the grade of endothelial dysfunction (15). They found that endothelial dysfunction was related to increased homocysteine levels and the total reduction of L-arginine and L-citrulline levels after surgery. The inactivation of methionine synthase is associated with the dose of $\mathrm{N}_{2} \mathrm{O}$, therefore, the dose and the duration of $\mathrm{N}_{2} \mathrm{O}$ exposure should be evaluated for endothelial dysfunction. It has been shown that the rate of enzyme inactivation is over with increased inspired concentration of $\mathrm{N}_{2} \mathrm{O}$ (2). Badner et al. reported that $\mathrm{N}_{2} \mathrm{O}$ exposure was associated with cardiac ischemic events and increased homocysteine levels in ninety patients during general anesthesia (16). In another study, it was shown that risk of myocardial infarction increased after using $\mathrm{N}_{2} \mathrm{O}$ in a clinical study with 2050 surgical patients (2).

Decreases of CD were compensated by way of cell spreading that resulted in increased cellular pleomorphism and a decrease in the percentage of hexagonal cells (6). In some studies it was shown that CD, Hex, and pachymetry decrease with aging and origins (17). Duman et al. reported that mean CV in cell size was $34 \pm 7$ (range 263-522) and the mean percentage of hexagonal cells was $46 \pm 8 \%$ (range $25-76 \%$ ) in a population aged between 6 and 85 years (18). In Elbaz's study, the mean endothelial cell density under the age of 5 was $3746 \pm 370$ (range $3145-5013$ ) cells $/ \mathrm{mm}^{2}$. Decline in $\mathrm{CD}$ is rapid in the first 2 years of life and this decrease is correlated with age. $\mathrm{CD}$ decreases to adult sizes when the cornea reaches its adult form (19). Gao 
et al. noticed that central corneal thickness increased in diabetics while $C D$ decreased $(\mathrm{p}<0.05)(18)$. Sati et al. suggested that endothelial $C D$ values decreased in patients with chronic renal failure because of raised blood urea level (20). Similarly, it was shown that raised plasma urea levels affected the corneal endothelium and endothelial parameters $(4,20)$. In addition, it was reported that corneal thickness (pachymetry) values increased in dialyzed patients who had chronic renal failure. In this study, there was a significant change only at the first postoperative week in the corneal variation and hexagonality rate values of the pediatric patients who underwent general anesthesia with $\mathrm{N}_{2} \mathrm{O}$. There was no significant difference between the groups in terms of $\mathrm{CD}, \mathrm{CV}$, Hex, pachymetry at other times.

In conclusion, possible effects of $\mathrm{N}_{2} \mathrm{O}$ on the corneal endothelium were noticed in our study. A statistically significant change was observed at the first postoperative week in the corneal variation and hexagonality rate values of the pediatric patients who underwent general anesthesia with $\mathrm{N}_{2} \mathrm{O}$. More studies investigating the effects of $\mathrm{N}_{2} \mathrm{O}$ on corneal endothelium need to be done for further assessment.

\section{Limitations}

It should be noted that this study has some limitations. First, it did not investigate the plasma homocysteine concentrations in the patients while $\mathrm{N}_{2} \mathrm{O}$ exposure effects increased postoperative homocysteine levels significantly. The correlation between plasma homocysteine concentration and the duration of exposure to $\mathrm{N}_{2} \mathrm{O}$ was not evaluated. Further studies should investigate the effects of the $\mathrm{N}_{2} \mathrm{O}$ exposure duration on the corneal endothelium. Secondly, volatile anesthetics, propofol and opioids might affect the conclusion of our study because of the chance of improving endothelial function (13).

\section{Ethical Approval Statement}

This study was carried out in accordance with the Clinical Research Ethics Committee (reference number 2017/95) of the Inonu University.

\section{Funding Disclosure Statement}

The study received no external funding.

\section{Conflict of Interest Statement}

The authors declare no conflict of interest.

\section{REFERENCES}

1. Kowalski C, Zahler S, Becker BF, Flaucher A, Conzen PF, Gerlach E, et al. Halothane, isoflurane and sevoflurane reduce postischemic adhesion of neutrophils in the coronary system. Anesthesiology. 1997;86:188-95.

2. Myles PS, Leslie K, Chan MTV, Forbes A, Paech MJ, Peyton $\mathrm{P}$. A review of the risks and benefits of nitrous oxide in current anaesthetic practice. Anaesth Intensive Care. 2004;32:165-72.

3. Ermens AA, Refsum H, Rupreht J, Spijkers LJ, Guttormsen AB, Lindemans J, et al. Monitoring cobalamin inactivation during nitrous oxide anesthesia by determination of homocysteine and folate in plasma and urine. Clin Pharmacol Ther. 1991;49:385-93.

4. Nunn JF. Clinical aspects of the interaction between nitrous oxide and vitamin B12. Br J Anaesth. 1987;59:3-13.

5. Bellamy MF, McDowell IF, Ramsey MW, Brownlee M, Bones C, Newcombe RG, et al. Hyperhomocysteinemia after oral methionine load acutely impairs endothelial function in healthy adults. Circulation. 1998;98:1848-52.

6. Qazi Y, Wong G, Monson B, Stringham J, Ambati BK. Corneal transparency: genesis, maintenance and dysfunction. Brain Res Bull. 2010;81:198-210.

7. Waring GO, Bourne WM, delhasuer HF, Kenyon KR. The corneal endothelium, normal and pathologic struc ture and function. Opthalmology. 1982;89(6):531-90.

8. Mc Dermott ML, Atluri HKS. Corneal endothelium. Ophthalmology, ed. Yanoff M, Ducker JS, trans. Bavdek T, 2. ed. Istanbul: Hayat Publishing; 2007:422-30.

9. Lehmberg J, Waldner M, Baethmann A, Uhl E. Inflammatory response to nitrous oxide in the central nervous system. Brain Res. 2008;1246:88-95.

10. Fee JP, Thompson GH. Comparative profiles of the inhaled anaesthetics. Durg Saf. 1997;16(3):157-70.

11. Weber NC, Preckel B, Schlack W. The effects of anesthetics on the myocardium: new insights into myocardial protection. Eur J Anaesthesiol. 2005;22:647-57.

12. Polat N, Ozkan AS, Gunduz E, Ulucan PB, Colak C. The effect of sevoflurane anesthesia on the corneal endothel. J Turgut Ozal Med Cent. 2017;24(3):261-4.

13. Ventura AC, Walti R, Bohnke M. Corneal thickness and endothelial density before and after cataract surgery. Br J Opthalmol. 2001;85(1):18-20.

14. Liou SW, Chiou CJ, Wang IJ. Effect of intracameral injection of lidocaine and carbachol on the rabbit corneal en- 
dothelium. J Cataract Refract Surg. 2004;30(6):1351-5.

15. Myles PS, Chan MTV, Kaye DM, Mcllroy DR, Lau CW, Symons JA, et al. Effect of nitrous oxide anesthesia on plasma homocysteine and endothelial function. Anesthesiology. 2008;109:657-63.

16. Badner NH, Drader K, Freeman D, Spence JD. The use of intraoperative nitrous oxide leads to postoperative elevations in plasma homocysteine. Anesth Analg. 1998;87:711-3.

17. Joyce NC. Proliferative capacity of corneal endothelial cell. Exp Eye Res. 2012;95(1):820-3.

18. Duman R, Çevik MT, Çevik SG, Duman R, Perente İ. Corneal endothelial cell density in healthy Caucasian population. Saudi J Opthalmol. 2916;30:236-9.
19. Elbaz U, Mireskandari K, Tehrani N, Shen C, Khan MS, Williams S, et al. Corneal endothelial cell density in children: normative data from birth to 5 years. Am J Ophthalmol. 2017;173:134-8.

20. Sati A, Moulick PS, Shankar S, Gupta S, Khan MA, Dogra $\mathrm{M}$, et al. Corneal Endothelial Alterations in Chronic Renal Failure. Cornea. 2016;35(10):1320-5.

21. Boillot A, Haddad E, Vallet B, Barale F. Effects of anesthetic agent on arterial reactivity. Ann Fr Anesth Reanim. 1999;18:415-29. 